

\section{Panta Rei \\ Revista Digital de Ciencia \\ y Didáctica de la Historia}

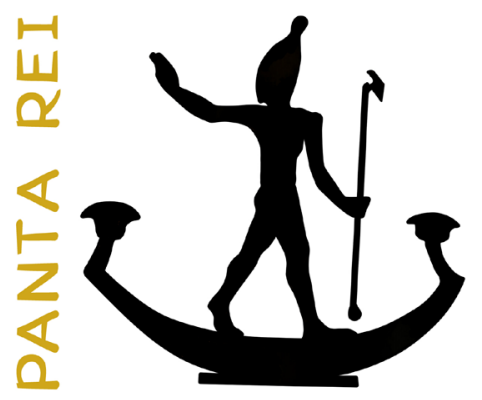

2017

Revista anual

Fecha de inicio: 1995

Revista Panta Rei. pantarei@um.es

Edita:

Centro de Estudios del Próximo Oriente y la

Antigüedad Tardía - CEPOAT

Edificio Universitario Saavedra Fajardo.

Universidad de Murcia

C/ Actor Isidoro Máiquez, 9

30007 - MURCIA - ESPAÑA

Teléfono: (+34) 868883890

cepoat@um.es

Web: www.um.es/cepoat/pantarei

Edición 2017

ISSNe: 2386-8864

ISSN: 1136-2464

Depósito legal: MU-966-1995
cepoAt

UNIVERSIDAD DE MURCIA centro de estudios del próximo oriente y la antigüedad tardia

En Portada: Kaaba durante el Ramadán. Fotografía de Abdullah Shakoor. Creative Commons CCO.

Responsables de los textos: Sus autores.

Responsable de la presente edición: Consejo Editorial Panta Rei. 


\section{CONSEJO DE REDACCIÓN}

\section{Coordinador editorial}

Egea Vivancos, Alejandro

[Didáctica de las Ciencias Sociales, UMU]

\section{Editores}

Botí Hernández, Juan Jesús

[CEPOAT, UMU]

Meseguer Gil, Antonio José

[UNED]

Sáez Giménez, David Omar

[CEPOAT, UMU]

Sánchez Mondéjar, Celso Miguel

[Patrimonio Inteligente]

\section{Secretaria}

Arias Ferrer, Laura

[Didáctica de las Ciencias Sociales, UMU]

\section{Responsable informático}

Martínez García, José Javier

[CEPOAT, UMU]

\section{Traducción y corrección lingüística}

Martínez Martínez, Cristina

[Sociedad Española de Lenguas Modernas]

Albaladejo Albaladejo, Sara

[ISEN, UMU]

\section{CONSEJO ASESOR}

Albero Muñoz, M. ${ }^{a}$ del Mar

[H. ${ }^{a}$ del Arte, UMU]

Chapman, Arthur

[History Education, UCL, Reino Unido]

Cobacho López, Ángel

[Derecho, UMU]

Egea Bruno, Pedro M. ${ }^{a}$

[Historia Contemporánea, UMU]

García Atienzar, Gabriel

[Prehistoria, UA]

González Monfort, Neus

[Didáctica de las Ciencias Sociales, UAB]

Haber Uriarte, María

[Prehistoria, UMU]

Hutson, Scott R.

[Anthropology, UK, EEUU]

Irigoyen López, Antonio

[Historia Moderna, UMU]

Mahony, Simon

[Digital Humanities, UCL, Reino Unido]

Marsilla de Pascual, Francisco Reyes

[Técnicas historiográficas, UMU]

Miralles Maldonado, José Carlos

[Filología Clásica, UMU]

Molina Gómez, José Antonio

[Historia Antigua, UMU]

Noguera Celdrán, José Miguel

[Arqueología, UMU]

Pérez Molina, Miguel Emilio

[Filología Clásica, UMU]

Prados Martínez, Fernando

[Arqueología, UA]

Sánchez Ibáñez, Raquel

[Didáctica de las Ciencias Sociales, UMU]

Sancho Gómez, Miguel Pablo

[Educación, UCAM]

Vilar García, María José

[Historia Contemporánea, UMU]

Zamora López, José Ángel

[Próximo Oriente Antiguo, CCHS-CSIC] 

Artículos

Entre el mito y la historia: el Éxodo de los israelitas desde Egipto a Canaán.

David Villar Vegas.

El Cerro de la Ermita de La Encarnación (Caravaca de la Cruz, Murcia): santuario y territorio en el mundo ibérico del Sureste peninsular.

Leticia López-Mondéjar.

Estelas discoideas y mundo funerario en la Asturias antigua.

Narciso Santos Yanguas......

Filosofía y paganismo en las postrimerías del Imperio Romano de Occidente. El caso del cónsul Mesio Febo Severo.

Rafael González Fernández y Miguel Pablo Sancho Gómez.

Dinámicas identitarias en el Mundo Actual: la religión como identidad frente al otro.

Rafael Ruiz Andrés y Francisco Javier Fernández Vallina.

El patrimonio fenicio-púnico. Claves para su socialización, puesta en valor y uso didáctico.

Helena Jiménez Vialás.

¿Cómo se enseña la llustración en $22^{\circ}$ de Bachillerato? Un análisis de los libros de texto, sus contenidos y la cuestión de género.

Helena Rausell Guillot..... 109

The Role of Local History in Elementary and Secondary Schools in Slovenia: An Evaluation of the Centre for School and Outdoor Education.

Danijela Trškan

Reseñas

Richardson, S. y Garfinkle, S. (eds.) (2016). Scholarship and Inquiry in the Ancient Near East (=Journal of Ancient Near Eastern History special issue, vol. 2/2, 2015) Berlin: de Gruyter. 179 págs.

Juan Álvarez García.

Guldi, J. y Armitage, D. (2016). Manifiesto por la Historia (traducción de Galmarini, M. A. The History Manifesto, 2014). Madrid: Editorial Alianza. 292 págs.

Juan Jesús Botí Hernández y David Omar Sáez Giménez.....

Normas de publicación/Publishing rules 



\title{
The Role of Local History in Elementary and Secondary Schools in Slovenia: An Evaluation of the Centre for School and Outdoor Education
}

\author{
El papel de la Historia local en escuelas primarias y secundarias en Eslovenia: la \\ evaluación del centro escolar y extracurricular
}

Recibido: $11 / 10 / 2016$

Danijela Trškan

University of Ljubljana, Slovenia

Aceptado: 20/01/2017

Para citar este artículo: Trškan, D. (2017). The Role of Local History in Elementary and Secondary Schools in Slovenia: An Evaluation of the Centre for School and Outdoor Education. Panta Rei. Revista Digital de Ciencia y Didáctica de la Historia, 123-134.

ISSNe: 2386-8864

DOI: $10.6018 /$ pantarei/2017/8

\begin{abstract}
The aim of the article is to investigate which elementary and secondary school subjects cover topics related to local history, what kind of activities are offered by the Centre for School and Outdoor Education, and what is the role of local history in understanding national, European and world history in Slovenia. Analysing the programme and activities of the Centre, it becomes evident that the Centre offers suitable methods and activities for those social science subjects that relate to various locations in Slovenia. Learning outside the classroom and exploring the hometown enable students to better understand the people, events and everyday life in the past, the changes and continuities and their reasons and consequences, as well as the needs, rights and responsibilities of people living in the present. On this basis, the article suggests that knowledge of local history provides an important basis for the understanding of the regional, national, European and global environment.
\end{abstract}

\section{Keywords}

Extracurricular Activities, Educational Environment, Teacher Education, Program Evaluation.

\section{Resumen}

El objetivo del artículo es investigar qué asignaturas de la escuela primaria y secundaria contienen los elementos de la historia local, qué tipos de actividades se ofrecen en el CŠOD (Centro de actividades escolares y extracurriculares de Eslovenia), y qué papel tiene la historia local en la comprensión de la historia nacional, europea y mundial en Eslovenia. El análisis del programa y las actividades del centro han evidenciado que el CŠOD ofrece métodos y actividades apropiados para las asignaturas de ciencias sociales relacionadas con diversos lugares de Eslovenia. El aprendizaje fuera del aula y la exploración del lugar natal permiten a los estudiantes entender mejor a las personas, los acontecimientos y la vida cotidiana del pasado, los cambios y las continuidades, junto a sus razones y consecuencias, así como las necesidades, los derechos y las responsabilidades

1 Contact details: Danijela Trškan. University of Ljubljana. Faculty of Arts. Department of History. Aškerčeva 2, 1000 Ljubljana. Slovenia. danijela.trskan@ff.uni-lj.si. 
de las personas que viven en el presente. Teniendo esto en cuenta el artículo sugiere que el conocimiento de la historia local proporciona una base importante para la comprensión del entorno regional, nacional, europeo y mundial.

\author{
Palabras clave \\ Actividades extracurriculares, Ambiente educativo, Formación del profesorado, Evaluación de \\ Programas.
}

\title{
1. Introduction
}

If we want the true image of the past to come to life before their eyes and history lessons to be integrated into reality, then we should make use of factual evidence and the visible traces of the past ... owing to the teacher's activity, students become capable of observing what the past has left behind and connecting the 'small history' of their town with the big history of the world.

(Zgonik, 1974, p. 330)

The awareness of one's hometown means that students try to understand the people, events and societies of the past; the changes and continuities, the reasons and consequences; the people and their needs; and, in particular, the social conflicts and rules. When studying local history, students develop an attitude towards their surroundings, gain knowledge of the local environment, become more sensitive to social changes, and more easily integrate into and participate in the social environment (Fortin-Debart, 2004). The students become more aware of the wealth of their local history and their own roots, which is important in times of globalisation.

The Slovenian historian Potočnik (2009) suggests that teachers should include more local history into history lessons in order to preserve the cultural heritage, and devote more time to Slovenian customs, which represent the cultural and spiritual tradition of the nation. Local history contents could be incorporated into all school subjects, particularly into history lessons. Thus students would study the past or present of their town, have access to various sources, and become involved in various school projects or individual school research studies. Croix and Guyvarc'h (1990) believe that local history is a sort of bridge between school history and collective memory, as it provides the students with knowledge and memories of their hometown.

In the following paper we would like to investigate which elementary and secondary school subjects cover topics related to the students' hometown; what is the role of the Centre for School and Outdoor Education and what sort of a programme does it propose; and what kind of activities are offered by the various residential and daily centres all over Slovenia. We will also evaluate the contents and tasks of activities that take place outside of school. These questions were addressed by means of document analysis (school curricula, subject syllabi and programmes of a series of residential centres for school and outdoor education). In conclusion, the paper stresses the role of local history in the understanding of the contemporary world.

\section{Local History in Elementary and Secondary Schools in Slovenia}

History is a very important subject in elementary and secondary schools in Slovenia. In addition to the primary, informative role of learning history - teaching the learners about the most important events from the local, national, European, and world history - school history has two other important roles: the functional role (training young people in historical thinking, reasoning, evaluation, and historical research) and the educational role (influencing the attitude and values of students, especially their reflective attitude towards the local, Slovenian and European environment).

The nine-year elementary school education is compulsory and free of charge. History is a 
compulsory subject from the $6^{\text {th }}$ to the $9^{\text {th }}$ grade (ages 12 to 15 ). In the $6^{\text {th }}$ grade, the contents are distributed in order to provide an introduction to the chronological approach in the $7^{\text {th }}, 8^{\text {th }}$ and $9^{\text {th }}$ grade. From the $7^{\text {th }}$ to the $9^{\text {th }}$ grade, the contents are divided into general (world or European) and Slovene history from prehistory to the $20^{\text {th }}$ century, with a special emphasis on the everyday life in different historical periods. During history lessons, students become aware of how important it is to maintain and protect the sources as well as practice how to trace the sources for research into local history by themselves.

The elementary school history curriculum (Kunaver et al., 2011) recommends visits to museums, libraries, galleries and archives, so that students can develop the ability to search for and gather new information and develop a respectful and responsible attitude towards the preservation and protection of cultural heritage. The curriculum states that: diverse examples and models can promote the understanding of life, activity, mentality and creativity in the individual periods of human history as well as enable students to know and understand themselves as individuals and members of the local community and society (Kunaver et al., 2011, p. 4).

Secondary education is also free of charge, but not compulsory. General secondary education (ages 15 to 19) is carried out at general secondary schools (general, classical, and professional) and finishes with a final exam. Professional schools have three specialisations: technical, arts, and economics. History is a compulsory four-year subject at general and classical secondary schools, a compulsory three-year subject at professional secondary schools, and a one-year compulsory subject at the various secondary technical schools. According to the secondary school curriculum, the $1^{\text {st }}$ year covers the period of prehistory and antiquity, the $2^{\text {nd }}$ year covers the period of the Middle Ages, the age of Humanism and the Renaissance, the age of Absolutism and the beginnings of industrialisation. The contents of the $3^{\text {rd }}$ year relate to the $19^{\text {th }}$ century, while the contents in the $4^{\text {th }}$ year relate to the $20^{\text {th }}$ and $21^{\text {st }}$ centuries (Kunaver et al., 2008b). The subject of history in different secondary technical schools involves the local, Slovenian and European history in the $19^{\text {th }}$ and $20^{\text {th }}$ centuries (History, 2007). The general secondary school curricula for history (Kunaver et al., 2008a; Kunaver et al., 2008b) emphasise that only elective topics can relate to local history and encourage a positive attitude towards the local cultural heritage in students. Meanwhile, the history curriculum for technical secondary schools (History, 2007) encourages the exploration of local history and suggests that students visit museums, local historical features and the old town centres in order to foster a positive attitude towards the preservation of Slovenian cultural heritage.

The analysis of different subject syllabi in elementary schools shows that several other subjects also include topics related to the students' hometown. For example, the local history is most often related to the natural and geographical features (in science, social studies, geography, ethnology, art history, tourism education, environmental education, hometown history exploration, hometown exploration and environment protection); to family (in science, social studies, civic education, civic culture, ethnology, religions and ethics); and to the cultural heritage (in science, social studies, geography, Slovenian language, music, art history, tourism education, ethnology, hometown history exploration, hometown exploration and environment protection) (Elementary School Syllabi, 2016/17; Trškan, 2008). The only subject in elementary schools that focuses entirely on the local history is the optional subject "Hometown History Exploration", which covers four topics: medieval stories, how we travelled, Slovenians as soldiers, and migrations throughout history. Within the scope of this subject, students explore their hometown in the form of cooperative learning or project work, visit museums or archives, and go on shorter excursions (Balkovec, Brodnik, Bregar, Galjot \& Snoj, 2008).

In secondary schools, the local history is also most often related to the natural and geographical features (in geography, social sciences, fine arts, music, art history, environmental studies); to cultural heritage (in geography, fine arts, social sciences, music, art history, environmental studies and Slovenian language); and to care for the preservation of the environment (in geography, fine arts, social studies, sociology, environmental studies) (Secondary School Syllabi, 2016/17; Trškan, 2008).

Developing a positive attitude to the environment and heritage and educating the students to 
care for their hometown are the most common teaching aims in the secondary-school as well as in elementary-school syllabi. For example, at geography the students are trained in studying and researching the home region. At art history lessons the students are supposed to present the cultural heritage of Slovenia as the basis of national self-awareness and one of the foundations on which the Slovenian national identity has been built, as an original way of comprehending the world. At social sciences the students are trained to assume the responsibility for cultural and historical heritage, for themselves, as well as for the natural and social environment. During history classes the students evaluate the cultural heritage in general as well as on the national level. They become aware of how important it is to carry on the Slovenian cultural tradition and develop the basic European cultural and civil values (Trškan, 2008).

The analysis of the teaching approaches in elementary and secondary schools has shown a considerable importance of the learner's independent work and research, group work, fieldwork and project work, and especially of the method of working with pictorial and written sources. All these approaches are suitable for studying the local history outside the classroom.

\section{The Importance of Activities Outside the Classroom}

Activities, suitable for education outside the classroom, include those that require students to proceed through every problem-solving phase, namely from detecting and defining the problems; through seeking and testing solutions, interpretation and evaluation; to presenting the findings and conclusions (Rutar Ilc, 2003). It is not enough to keep the students "busy": what is more important is the quality of their work (Strmčnik, 2001, p. 135).

There are many approaches to fieldwork. Ashley (1999) mentions three methods. The first method is observation, which usually includes guided tours and walks, with the teacher guiding the learning process and the students remaining passive (e.g. taking notes or drawing sketches). The second method is investigation, in which the students are more active (e.g. observing, measuring, taking notes, answering questions). In the case of discovery learning (the third method), the students suggest ways of gathering information. This method contains elements of problem solving, discussing problems, and teamwork.

Each urban or rural environment contains traces of the past human activity. These traces are everywhere: buildings, streets, bridges, monuments, names of shops, cafés and restaurants, locations of public or private houses. The goal is not merely to observe the historical environment, but to discover and explore the environment with the aim of better understanding the lifestyle of people in the past, planning further changes and constructions, and identifying the reasons for and consequences of the human impact on the environment (Waterfiled, 2004).

The study of local history most often centres on houses and buildings, rooms, castles, gardens and parks, industrial buildings, objects, museum or archival material. The contents for studying local history are diverse, e.g. the history of a town (first mention of the town, origin of the town name), the history of the local churches, World War I and II in the town, the history of companies or factories, the history of the schools, first and last names in the town, the role of squares, the naming of streets, means of transport, the hometown on postcards or in archival sources, public utility activities, inns, street lighting, cemeteries, tourist events in the town, trade, medical care, communications (telephones, radio receivers, television, computers), environmental pollution (landfills, skips and dustbins), weather, natural disasters, etc. Furthermore, Weber (1994) confirms that one of the important means of valuing our own cultural heritage is the in-depth factual knowledge of the formation of one's hometown, of the reason for its formation and development, and the knowledge of its people's achievements.

Our hometown stirs up creative imagination as it helps us understand the historical past, society, the way of life and work of the people. Since the buildings and facilities in our hometown are a part of the local identity, they represent a sense of affiliation with the specific surroundings. On the one hand, the environment triggers an awareness of affiliation with an area, and, on the other hand, 
an understanding of the surroundings in which we are living (Waterfiled, 2004).

Woolfolk (2002), for example, suggests that the learning environment in nature should incorporate activities which imitate the real-life problems and situations, whereas Rutar Ilc (2003) adds that when solving tasks, students should get the impression that these tasks are related to real life and therefore sensible and worth the effort.

The various activities, connected with the exploration of our hometown, contribute to creative, innovative, exploratory, constructive and experiential work, e.g. making a newsletter; preparing a television show; putting together an exhibition of the oldest photographs or objects; planning a learning trail; writing recipes; making a website, or organising a round table on the issues of the hometown. We can conclude that education outside the classroom is the best opportunity for getting to know, explore and research one's hometown. Furthermore, it is also the basis for exploring the broader area.

\section{The Programme and Activities of the Centre for School and Outdoor Education}

There are 24 residential centres in Slovenia where learning outside the classroom is possible for elementary and secondary school students, who most often spend a week or five days there. These centres fall under the Slovenian Centre for School and Outdoor Education and offer many opportunities for learning about and studying the local history of the specific areas in Slovenia (CŠOD, 2015a).

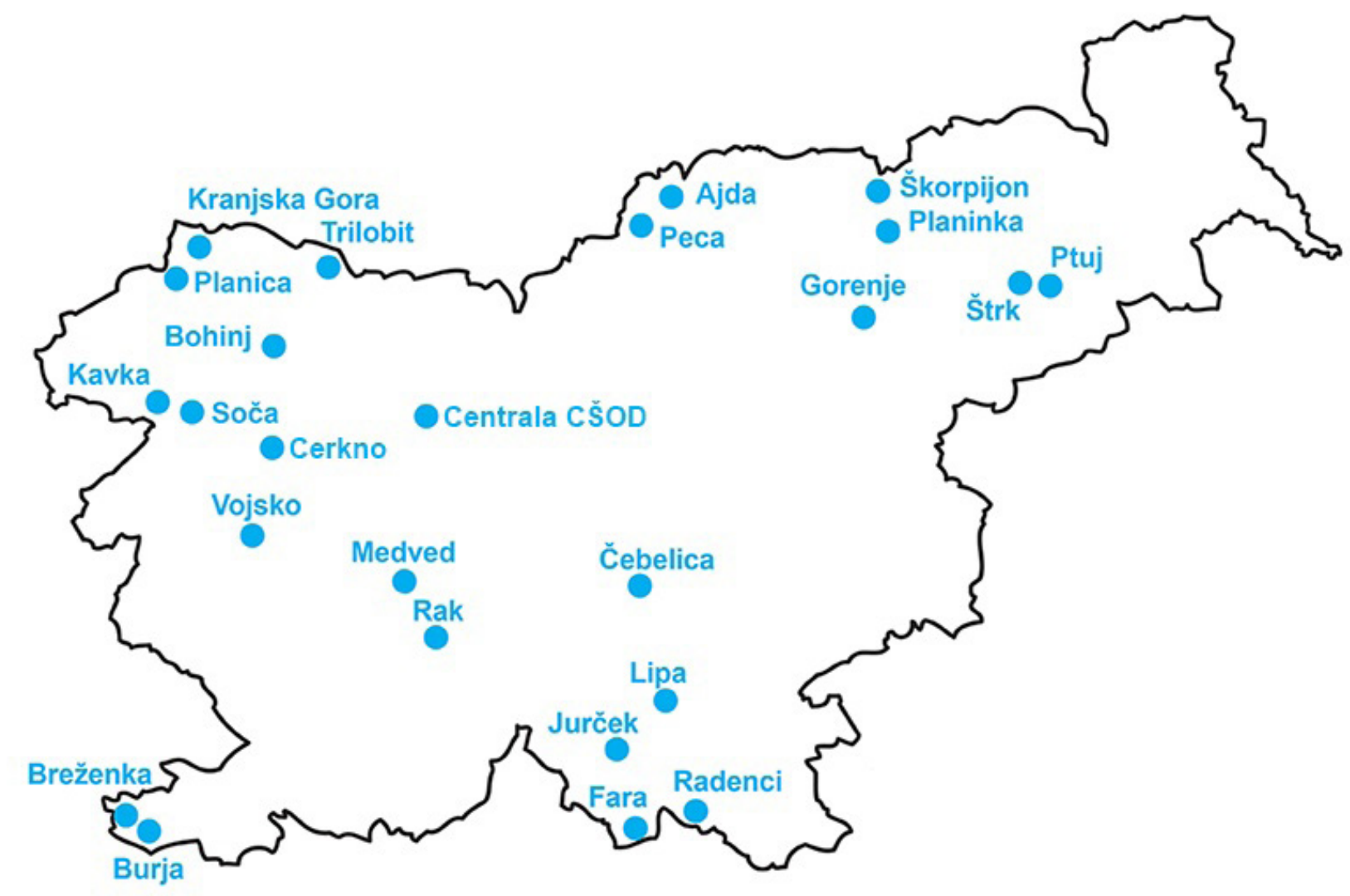

Figure 1. Residential Centres in Slovenia (CŠOD, 2016b)

The Slovenian Centre for School and Outdoor Education also runs daily centres, enabling students to familiarise themselves with the various parts of Slovenia, especially by visiting museums, 
natural monuments, caves, etc.

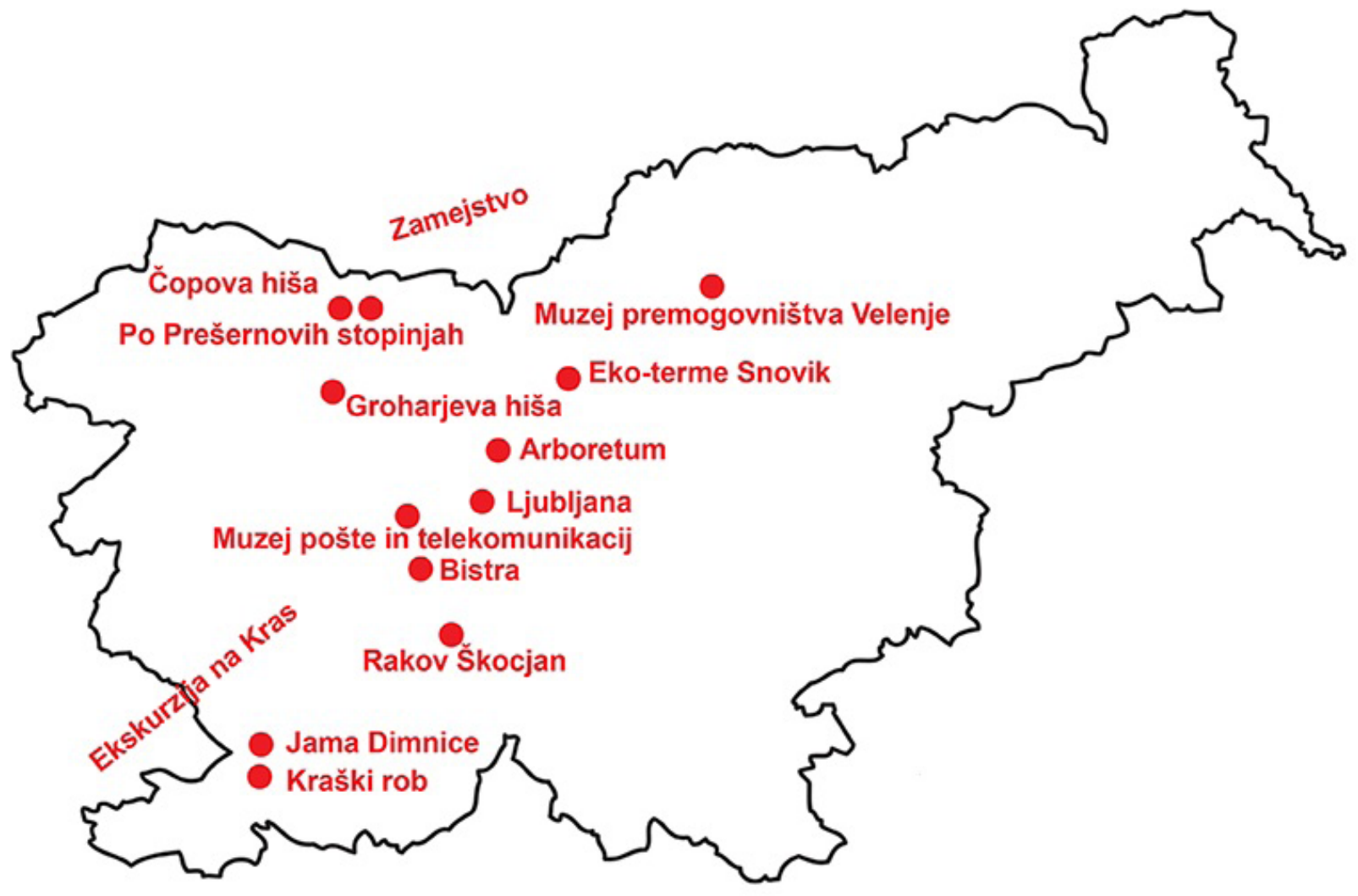

Figure 2. Daily Centres in Slovenia (CŠOD, 2016a)

We have established that the residential and daily centres are distributed across the various parts of Slovenia and offer not only opportunities for sports activities (Alpine skiing, winter games, sledding, snowboarding, walking and cross-country skiing, hiking, mountaineering, cycling, kayaking, canoeing, etc.) and natural science activities (in the field of environmental education, natural sciences and techniques, biology, home economics, health education, etc.), but also offer various social science activities (in the field of history, geography, sociology, social studies, etc.), from observation and discovery to studies and independent research work of local history.

The activities involved in the education outside the classroom enable teachers to reach many objectives of elementary and secondary school education, such as the development of a positive and responsible attitude towards the environment, student socialisation or group education in mutual tolerance, respect for diversity, development of capacities for living in a democratic society, and promoting friendship and mutual assistance (CŠOD, 2015b).

We have established that education outside the classroom also ensures other objectives, which are harder to implement during school lessons. It is one of the few forms of education in which the cognitive, physical, emotional, social, moral and aesthetic dimensions of education are rather evenly distributed (Kristan, 1998). Education outside the classroom promotes the personal growth of students; through various activities it introduces them to useful and healthy ways of spending their free time; and it contributes to the socialisation of students (Concept, 2001; Kristan, 1998).

The analysis of the programmes, offered by different residential and daily centres of the Centre for School and Outdoor Education, showed that they include historical and ethnographic contents (the life of people today and in the past, local crafts, dances, manners and customs, human impact on the transformation of landscape, vernacular architecture, garden styles, residences, cultural 
heritage); geographical contents (economic activities, transport and safety, tourism, population and settlement, parks, lakes, waterfalls, nature reserves, natural monuments, caves, thermal springs, mines, power plants, life and work on a farm, spatial orientation and cartography, definition of landscape, types of settlements and landscapes, domestic animals); sociological contents (living in a community, social rules, human rights, mutual relationships, cooperation, conflict resolution, free time, diet, hospitality, manners); cultural contents (homes of writers and poets, birthplaces of important figures); sports and social science contents (Alpine skiing gear in old times, games and sports in the past, orientation hikes and treasure hunting, educational field trips, survival in nature, traditional dances); environmental protection contents (sources of air pollution, problems due to air, water and soil pollution, waste disposal sites, impact of tourism on the natural environment, consumption and generation of electricity).

We can add that education outside the classroom enables the shifting of the learning process from schools to another location, thus introducing a diverse learning environment. The learning environment is used for learning, gaining knowledge, revising, deepening and broadening knowledge or for studying, discovering, and developing research and life skills. Education outside the classroom requires that teachers plan the research topics in accordance with the curriculum, that they are familiar with the terrain, plan the activities for the students, anticipate dangers in the field, cooperate with colleagues in the field, prepare the students in advance, and evaluate the work in school (Hoodless, Bermingham, McCreery \& Bowen, 2003).

The analysis of the teaching and learning methods, used in the social science programmes, showed that they are in line with the requirements of elementary and secondary school curricula. The Centre promotes, above all, the use of teamwork, role-playing, discussions, problem solving in real-life situations, and project work (CŠOD, 2002).

The analysis of the activities offered by the Centre shows that education outside the classroom can take place in the form of workshops where students learn by exploring their town, based on their own interests, learning contents and objectives of individual subjects: e.g. literary (creative writing), art (drawing past events), recitation (folk songs), history (studying the cultural, social and economic history), sociology (education for tolerance, peace, coexistence), culinary (cooking, collecting recipes), sports (games of ancestors), theatre (performances about the students' hometown), dance (folk dances), photography, sculpture, music, multimedia, ethnology (manners and customs of people), religion (folk beliefs in the past), entrepreneurial (business planning), journalism (polling the locals), puppet (puppet shows), and other workshops (CŠOD, 2015a).

One example which can illustrate the implementation of outdoor education at elementary schools is the topic of migrations. The students can illustrate the migration flows that had affected their home village or town after the Second World War. Using the sources and data collected during fieldwork, they can present the life stories of people from their hometown in order to explain the processes of emigration and migration. They can try to find out how well the local population remembers migrations; record and analyse the memories of people who have returned to their hometown. They can attempt to estimate the extent to which people have migrated from their homes to the nearby villages or towns in the past and nowadays and try to find the reasons, etc. (Balkovec et al., 2008). Another example is the project week on the issue of waste, which can be connected with outdoor education at elementary or secondary schools. Students can interview older people and find out what different sorts of waste can tell us about the life of people in the past (Kavčič, 2013).

All residential centres of the Centre for School and Outdoor Education report that many schools in Slovenia choose their weekly activities as extra-curricular activities. The majority of these are elementary schools, but the number of secondary schools and faculties increases each year as well. The teachers find the residential centres very well organised and think that their programmes fit very well in the school curricula, especially at the elementary level (Gradišar, 2016).

We conclude that the programme of the Centre for School and Outdoor Education is an excellent supplement to the school curriculum at the elementary and secondary level. It allows for the attainment of the learning objectives and standards of the official school curriculum in a natural and authentic 
way by providing various activities. For example, students can develop their ability in orientation in time and space; understand the life, work and mentality in the past and present; understand the basic characteristics and key problems of the modern world; become active individuals involved in the responsible management of the environment and nature; gain the knowledge, abilities and skills for the integration into professional life and society. Students become aware of the values and uniqueness of the Slovenian landscape, and develop a positive and respectful attitude towards the natural and cultural heritage of Slovenia by studying the local environment.

The analysis of the programme of the Centre for School and Outdoor Education showed that it is compatible with the content requirements of the elementary and secondary school curricula in Slovenia and that it offers many possibilities for deepening the knowledge of the local history and local environment. The Centre offers many possibilities for carrying out different activities and for the active participation of students in the learning process based on fieldwork and experiential learning.

\section{The Role of Local History in Understanding European and World History}

The research into local history also includes the European and global dimension. The locality can be studied "as a case study of changes and developments which have taken place across Europe, or across regions within Europe, albeit at different rates" (Stradling, 2001, 158). It is easier to first choose and carefully study a narrow, local case of the historical event that we want to present, and only then generalise it and set it into broader space and time (Weber, 1981). Using modern technology and the Internet, local history can be quickly compared with the local history of other places and towns. The Internet enables students to look up various towns, their buildings, monuments, museums, archives, etc., and compare them with their hometown.

Clio (2003) suggests that the following elements be included in the school curricula: spatial frame, time frame, concepts (e.g. community, autonomy, centralism, citizenship, territory, landscape, square, town), questions and problems, research methods, material and equipment, connections with general history and the broader context, local history and other subjects, recommended literature and used sources. Thus the curricula in all European countries could cover topics such as territory, the environment, landscape, social history, economic history, history of thought, political and administrative history, and so on. Students could study sources at various public institutions, e.g. in the public and local archives (schools, companies, the state) and museums or study the cultural heritage of their respective towns (architecture, archaeology, landscape, urban planning). Moreover, the size of the area could be limited to the surroundings, the town or to the broader area, the city or region. In doing so, various teaching and learning methods would have to be used, as well as various sources. For younger students, e.g. elementary school pupils, the narrower surroundings would be used at first, particularly the social and economic history; whereas secondary school students would delve into political and administrative topics, mentality, customs and lifestyles (Clio, 2003).

Contents related to the students' hometown are also an integral part of civic education and culture. Not only various examples from national history, but also various examples from local history qualify students for a deeper and consistent connection with broader historical phenomena and for merging them into a logical, clear whole (Weber, 1981). For example, during history lessons the students study historical cases, which help them develop a certain sensibility for the values that are important for autonomous group work and life in a pluralist and democratic society (becoming tolerant and peaceful, being able to listen to people with different opinions with tolerance and at the same time being able to support their own opinion with arguments, working in mutual cooperation, respecting basic human rights and dignity).

Thus the main focus of citizenship and civic education includes freedom and authority, democracy and government (local, national, European), laws and courts, rights and responsibilities, public virtues and ethics, and institutions (Ashley, 1999). Social science subjects should present to the students the roles of people in the past; explain environmental problems, changes, continuities, reasons and consequences; and introduce the people and their needs, rules, rights, and responsibilities in the 
society.

Knowledge of the hometown cultural heritage represents the basis for the knowledge about the national and world cultural heritage. With it the students are equipped for independent and responsible work in the society, aware of their surroundings and of all that is going on around them, active in their town, and able to contribute to the development of their hometown. It is precisely education outside the classroom that can stimulate the desire of students to first explore their home region and town, and afterwards other countries as well.

The teaching of history in the democratic Europe should "enable European citizens to enhance their own individual and collective identity through knowledge of their common historical heritage in its local, regional, national, European and global dimensions" (Council of Europe, 2001, p. 3). The basis for the awareness about the global and European natural and cultural heritage is the knowledge of the local area. Social science activities and, in particular, various school or extracurricular activities (an example was given for the Centre for School and Outdoor Education in Slovenia) which include the exploration of the students' hometown, prepare the students for an active role as well as for independent and responsible work in the society. Learning by getting to know, exploring, studying, and researching their hometown, region and country - with the emphasis on social contents - is the basis for the global civic education of youth.

\section{Conclusion}

On the basis of the analysis of different Slovenian elementary and secondary subject syllabi, we can conclude that some topics relating to the hometown and local environment are included in certain elementary and secondary subjects (geography, art history, hometown history exploration, social studies, etc.), where the contents are mostly related to cultural heritage. More possibilities to include local history - in addition to the global, European and national history - are provided by history, which is an obligatory subject in the Slovenian elementary and secondary schools. We would like to underline the elementary school subject of hometown history exploration, which tends to focus more on the Slovenian national history rather than on topics directly connected with the students' hometown.

The comparison of elementary and secondary school syllabi has shown that the aims often mention a positive attitude to the immediate environment and to the heritage, which shows how important it is for the learners to know their local environment also when it comes to civic education and culture. We suggest that teachers try to include local history topics in the learners' homework or in additional assignments given during the lessons, in extracurricular activities, optional subjects, optional compulsory activities, school projects, out-of-school activities and school camps, etc. One of the ways to achieve this is also the cooperation of elementary and secondary schools with the Centre for School and Outdoor Education in Slovenia.

The Centre for School and Outdoor Education has considerable significance in Slovenia since it incorporates suitable teaching and learning methods for working outside the classroom, such as experiential learning and teamwork, in its various activities, and promotes a positive attitude towards the environment. The Centre offers numerous activities for education outside the classroom, which are divided into three sets: sports, natural science and social science activities. These activities relate to the various locations of daily activities and to the various locations of the residential centres in Slovenia. Since the Centre offers activities for social science subjects that relate to various locations in Slovenia, the learning contents relate or can be applied to specific Slovenian regions and to the broader environment.

The historical environment is all around us, and this means that each area offers evidence of the people's life and activity in the past. Researching local history can be inexpensive since each school has a historical building in its vicinity. Discovery learning in the hometown offers rich learning contents all by itself. The environment enables the attainment of various objectives (knowledge, abilities and behaviour) of the school curricula. Due to the global approach and interdisciplinarity, 
the local environment is a natural source of motivation, which enables teamwork and cooperation among teachers and students (Vigouroux, 2000, p. 7). The studying of local history lies in the tasks and activities which the students perform in the elementary or secondary schools. Through different activities in the field of local history, offered by the Centre for School and Outdoor Education, the students develop a sense of responsibility towards cultural and historical sites, grow accustomed to a positive evaluation of cultural heritage and to an active role in society, gain knowledge, understanding, values and abilities for protecting the environment, and develop the awareness of the local, regional and national identity and affiliation. We suggest that more schools in Slovenia choose the Centre for School and Outdoor Education for the organisation of out-of-school activities and school camps. Also, we agree with Kristan (1998) who suggests that the teachers should make use of every opportunity in the local environment for gaining new knowledge and broadening one's horizons because outside the classroom students can learn in detail about the natural science, geographical, historical, cultural, ethnological and other characteristics of the town in which they are living. We can add that education outside the classroom in the students' hometown triggers curiosity about observing the landscape, objects or products, and promotes various social values, such as kindness, friendship, solidarity, sociability, tolerance, fairness, hospitality, etc. Education outside the classroom also prepares students for an active role in a democratic society, and accustoms them to independent and responsible work throughout their life. Exploring the local environment also stimulates an internal interest of students in history, gives them a sense of personal identity when studying history, and contributes to the knowledge and understanding of the Slovenian social, economic, political and cultural history. Through local history, students come to know and explore the past of their hometown and home region, broaden their spatial and temporal orientation from their hometown and home region towards Slovenia, Europe, and the world. The knowledge of hometown development is extremely important for understanding the development of the contemporary world.

In conclusion, the study of local history in schools is a method of active integration into the local society, as students are being systematically and thematically introduced to the life and events in their hometown. This is important for independent functioning in the society, which is the basis for the global civic education in the $21^{\text {st }}$ century.

\section{References}

Ashley, M. (ed.) (1999). Improving Teaching and Learning in the Humanities. London: Falmer Press. Balkovec, B., Brodnik, V., Bregar Mazzini, S., Galjot, A., \& Snoj, D. (2008). Učni načrt. Izbirni predmet. Odkrivajmo preteklost svojega kraja [Curriculum. Selected Subject. Exploring the Past of the Hometown]. Retrieved from http://www.mizs.gov.si/fileadmin/mizs.gov.si/pageuploads/ podrocje/os/devetletka/predmeti_izbirni/Preteklost_kraja.pdf

Clio (2003). Theses on the Teaching and Learning of Local Histories by Clio '92, Association of Teachers and Researchers in History Teaching and Learning. Retrieved from http//www. eurocliohistory.org/

Concept (2001). Koncept. Šola v naravi za 9-letno osnovno šolo. [Education Outside the Classroom for Nine-Year Elementary School]. Retrieved from http://www.mszs.si/slo/ministrstvo/organi/ solstvo/viprogrami/os/9letna/pdf/sola_v_naravi.pdf

Council of Europe (2001). Recommendation Rec(2001)15 of the Committee of Ministers to Member States on History Teaching in Twenty-First-Century Europe. Retrieved from https:// pestalozziprogrammelibrary.wordpress.com/2015/01/04/recommendation-rec200115-of-thecommittee-of-ministers-to-member-states-on-history-teaching-in-twenty-first-century-europe/

Croix, A., \& Guyvarc'h, D. (eds.) (1990). Guide de l'histoire locale. Faisons notre histoire! Paris: Éditions du Seuil.

CŠOD (2002). V naravo z glavo. Zakaj pa ne? [Outside the Classroom with Head. Why not?]. Ljubljana: Centre for School and Outdoor Education.

CŠOD (2015a). Center šolskih in obšolskih dejavnosti [Centre for School and Outdoor Education]. 
Retrieved from http://www.csod.si/

CŠOD (2015b). Splošni cilji [General Aims]. Retrieved from http://www.csod.si/stran/splosni-cilji

CŠOD (2016a). Daily Centres in Slovenia. Retrieved from http://www.csod.si/center

CŠOD (2016b). Residential Centres in Slovenia. Retrieved from http://www.csod.si/dom

Elementary school syllabi, 2016/17. Retrieved from http://www.mizs.gov.si/si/delovna_podrocja/ direktorat_za_predsolsko_vzgojo_in_osnovno_solstvo/osnovno_solstvo/ucni_nacrti/

Fortin-Debart, C. (2004). Le partenariat école-musée pour une éducation à l'environnent. Paris: L'Harmattan.

Gradišar, B. (2016). PowerPoint Presentation of the Centre for School and Outdoor Education at Faculty of Arts - University of Ljubljana. Ljubljana: CŠOD.

History (2007). Zgodovina. Katalog znanja. Srednje strokovno izobraževanje. Poklicno-tehniško izobraževanje. [Knowledge Catalogue. Secondary Technical Education. Vocational-Technical Education]. Retrieved from http://portal.mss.edus.si/msswww/programi2008/programi/drugi_ del/SSI/KZ-IK/kZ_zgodovina_ssi_in_pti_103_126.doc

Hoodless, P., Bermingham, S., McCreery, E., \& Bowen, P. (2003). Teaching Humanities in Primary Schools. Exeter: Learning Matters Ltd.

Kavčič, I. (2013). Projektni tedni, celostni pristop in učenje za trajnostni razvoj. [Project Weeks, An Integrated Approach and Learning for Sustainable Development]. Didakta, XXII (161), 24-26.

Kristan, S. (1998). Šola v naravi [Education Outside the Classroom]. Radovljica: Didakta.

Kunaver, V., Brodnik, V., Gaber, B., Potočnik, D., Gabrič, A., Šifrer, M., Rode, M., Tawitian, E., \& Razpotnik, J. (2011). Učni načrt. Program osnovna šola. Zgodovina. [Curriculum. Programme of Elementary School Education]. Retrieved from http://www.mizs.gov.si/fileadmin/mizs.gov.si/ pageuploads/podrocje/os/prenovljeni_UN/UN_zgodovina.pdf

Kunaver, V., Gabrič, A., Brodnik, V., Razpotnik, J., Valič, A., Radosavljevič, B., Glaser Tehovnik, M., Bizjak, S., Zgaga, S., Globočnik, M., \& Globočnik, J. (2008a). Učni načrt. Zgodovina. Strokovna gimnazija. [Curriculum. History. General Professional Secondary School]. Retrieved from http://eportal.mss.edus.si/msswww/programi2015/programi/media/pdf/un_gimnazija/un_ zgo_210_ur_strok_gimn.pdf

Kunaver, V., Gabrič, A., Brodnik, V., Razpotnik, J., Valič, A., Radosavljevič, B., Glaser Tehovnik, M., Bizjak, S., Zgaga, S., Globočnik, M., \& Globočnik, J. (2008b). Učni načrt. Zgodovina. Splošna gimnazija. [Curriculum. History. General Secondary School]. Retrieved from http://eportal. mss.edus.si/msswww/programi2015/programi/media/pdf/un_gimnazija/un_zgodovina_280_ ur_gimn.pdf

Potočnik, D. (2009). Zgodovina, učiteljica življenja [History, Teacher of Life]. Maribor: Pivec.

Rutar Ilc, Z. (2003). Pristopi k poučevanju, preverjanju in ocenjevanju [Approaches to Teaching, Examination and Evaluation]. Ljubljana: The National Education Institute of the Republic of Slovenia.

Secondary schoolsyllabi, 2016/17. Retrieved from http://eportal.mss.edus.si/msswww/programi2016/ programi/index.htm

Stradling, R. (2001). Teaching 20th Century European History. Strasbourg: Council of Europe Publishing.

Strmčnik, F. (2001). Didaktika. Osrednje teoretične teme Didactics [The Central Theoretical Topics]. Ljubljana: Scientific Institute of the Faculty of Arts.

Trškan, D. (2008). The role of local history in primary and secondary schools today. In Tchibozo, G. (ed.), Proceedings of the Paris international conference on education, economy and society Paris 17-19 july 2008. Vol. 3, Mungaray - Zhang (pp. 399-409). Paris: Analytrics.

Vigouroux, J.-P. (2000). Eduquer à l'environnement en collèges et lycées: Enseignement général et agricole. Ecologistes de l'Euzière: Agence Méditerranéenne de l'Environnement.

Waterfiled, G. (ed.) (2004). Opening Doors: Learning in the Historic Environment. An Attingham Trust Report 2004. Hampton: The Attingham Trust.

Weber, T. (1981). Teorija in praksa pouka zgodovine $v$ osnovni šoli. [Theory and Practice of History 
Teaching in Elementary School]. Ljubljana: DZS.

Weber, T. (1994). Načrtovano (projektno) in celostno (integrirano) delo pri pouku zgodovine $v$ razredu ali na terenu (muzeju, galeriji in arhivu) [Design (Project) and Overall (Integrated) Work in History Lessons in the Classroom or Outside the Classroom (Museum, Gallery and Archive)]. Zgodovina $v$ šoli [History in School], 3 (1), 30-42.

Woolfolk, A. (2002). Pedagoška psihologija [Educational Psychology]. Ljubljana: Educy. Zgonik, M. (1974). Zgodovina v sodobni šoli [History in Modern School]. Ljubljana: DZS. 


\section{Panta Rei}

PANTA REI es una revista digital de investigación orientada a la Historia y otras ciencias afines. Su principal objetivo es la transmisión del conocimiento científico, dando una oportunidad también a los jóvenes investigadores que quieren abrirse camino en el estudio de las ciencias humanas y sociales. Se compone de estudios originales relacionados con la disciplina histórica así como su didáctica y difusión. Las diferentes secciones que componen la revista son: artículos de investigación, entrevistas a profesionales, recensiones de monografías de actualidad y crónicas de congresos o eventos científicos relevantes.

Todos los artículos publicados son objeto de un proceso de revisión a cargo de un mínimo de dos evaluadores, que se consideran expertos en el ámbito temático del artículo propuesto. Nuestro deseo es poder ofrecer unos contenidos rigurosos, de calidad y de interés.

EI CEPOAT (Centro de Estudios del Próximo Oriente y la Antigüedad Tardía de la Universidad de Murcia) es la institución encargada de la coordinación y gestión de la revista, desde donde anualmente se lanzará la convocatoria para aquellos que estén interesados en publicar sus trabajos, siempre relacionados con la Historia, Arqueología, Historia del Arte, Didáctica de las Ciencias Sociales, etc.

PANTA REI is a digital journal focused on History and other sciences related to it. Its main objective is the transmission of scientific knowledge by giving also an opportunity to young researchers who want to make their way in the study of human and social sciences. It is composed by original studies related to History, as well as its didactics and promotion. The different sections of this journal are: research articles, interviews to professionals, recensions on monographs about current issues and reports about congresses or relevant scientific events.

All the articles published are subject to a revision process carried out by a minimum of two reviewers who are considered to be experts in the field of the article proposed. Our wish is to offer rigorous contents with quality and being of interest to the reader.

CEPOAT (Centre of Studies of the Middle East and Late Antiquity of the University of Murcia) is the institution in charge of the coordination and management of this journal. This is the centre from where the call for papers will be launched for all the people interested in publishing their papers, always related to History, Archeology, Art History, Didactics of the Social Sciences, etc. 


\section{Normas de Publicación}

El autor se compromete a enviar trabajos originales, que no se encuentren publicados en otras revistas ni en otros idiomas. Así mismo, el mismo artículo no podrá ser presentado en otras revistas mientras dure el proceso de evaluación.

\section{Envío y presentación de originales}

Los artículos se enviarán exclusivamente a través del correo electrónico a la dirección pantarei@um.es. Los textos serán enviados en formato DOC y las imágenes en formato JPEG o TIFF, y con un tamaño mínimo de 2000 px. Éstas no aparecerán incorporadas en el texto, sino enviadas en archivo aparte y correctamente numeradas según su posición en el texto. Junto al trabajo, se rellenará y enviará un documento aparte en el que se especifiquen los datos del autor siguiendo el modelo disponible en la página Web de la revista.

Para la redacción de los trabajos se tendrá en cuenta el Manual de la American Psychological Association, en su sexta edición. La extensión máxima de los trabajos será de 30 páginas. La tipografía será Arial 11, con interlineado sencillo y sin espacio alguno entre párrafos. El texto deberá ir justificado a ambos márgenes y sin sangría en los primeros párrafos. Los márgenes serán de $2,50 \mathrm{~cm}$. En los casos en los que fuera necesario incorporar notas, éstas irán a pie de página, enumeradas consecutivamente, con tipografía Arial 10, interlineado sencillo y justificadas a ambos márgenes.

Una información más detallada se encuentra disponible en la página http://www.um.es/cepoat/ pantarei.

\section{Proceso de valoración y evaluación}

Una vez recibidos los trabajos, la Revista realizará una primera valoración. Si el trabajo enviado se ajusta a las normas de presentación propuestas, la temática es coincidente con la línea editorial de la revista y posee la calidad científica necesaria, será remitido al consejo asesor para una primera evaluación. Si no es así en este primer paso se puede rechazar directamente los documentos que incumplan claramente la línea editorial.

Será el Consejo Asesor quien indique a la revista la originalidad, relevancia, estructura, redacción, aparato bibliográfico, etc. del trabajo enviado y, para ello, se designará a dos revisores expertos externos que evaluarán cada uno de los trabajos, que pueden formar parte (o no) de este Consejo Asesor. La selección de los revisores se ajustará a la temática y características metodológicas del trabajo. El nombre y filiación de los autores serán eliminados del trabajo para su revisión, así como los revisores actuarán de manera anónima y confidencial.

Los revisores deberán rellenar un informe de evaluación que centrará su atención en aspectos tales como características formales, originalidad y novedad de los trabajos, relevancia de las propuestas y los resultados, calidad metodológica y validez científica.

Una vez terminado el proceso se decidirá la aceptación o no de los mismos y su publicación en el número que sea pertinente, así como las modificaciones susceptibles de ser realizadas para su final publicación. Dicha notificación se enviará únicamente por correo electrónico, en un plazo máximo de seis meses. 


\section{Publishing rules}

The author is committed to submit original papers not having been published in other reviews or in other languages. In this way, it is not allowed for the same paper to be presented in other reviews during the evaluation process.

\section{Submission and presentation of originals}

The articles will be exclusively submitted by email to pantarei@um.es. The texts will be submitted in DOC format and the images in JPEG or TIFF format, and with a minimum size of 2000 px. Images will not be integrated in the text but sent in another file and properly numbered according to their position in the text. Attached to the paper, a document will be filled out and sent where the author's data will be specified following the model available on the website.

The sixth edition of the Manual of the American Psychological Association will be taken into account for the writing of the papers. The length of the papers must not exceed 30 pages. Typography will be Arial 11 , with simple line spacing and no space between paragraphs. The text must be justified on both margins without indentation in the first paragraphs. Margins size will be $2.50 \mathrm{~cm}$. Where it could be necessary the incorporation of notes, they will be at the bottom of the page, consecutively numbered with typography Arial 10, simple line spacing and justified on both margins.

More detailed information is available on the website: http://www.um.es/cepoat/pantarei.

\section{Examination and assessment process}

The Journal will submit the papers to a first examination once received. If the paper follows the presentation guidelines, the subject agrees with the editorial line of this journal, and possess the scientific quality required, it will be sent to the advisory council for a first assessment. If not, the documents which clearly fail to complete the editorial line may be rejected straightaway in this first step.

The Advisory Council will indicate the originality, relevance, structure, writing, bibliography, etc. of the text to the journal; for this purpose, two outside experts will be designated to review the papers; these experts can be (or not) part of this Advisory Council. The selection of the experts will adjust to the subject and methodological characteristics of the paper. Name and affiliation of the author will be eliminated from the text for its review, in this way experts will act anonymously and confidentially.

The experts will fill out an assessment report which will focus on aspects such as formal characteristics, originality and novelty of the papers, relevance and results of the proposal, methodological quality and scientific validity.

Once the process is finished, the acceptance or not of the papers and its publication in the corresponding edition will be decided, as well as the modifications that may be done for its final publication. This notification will be sent by email within 6 months maximum. 



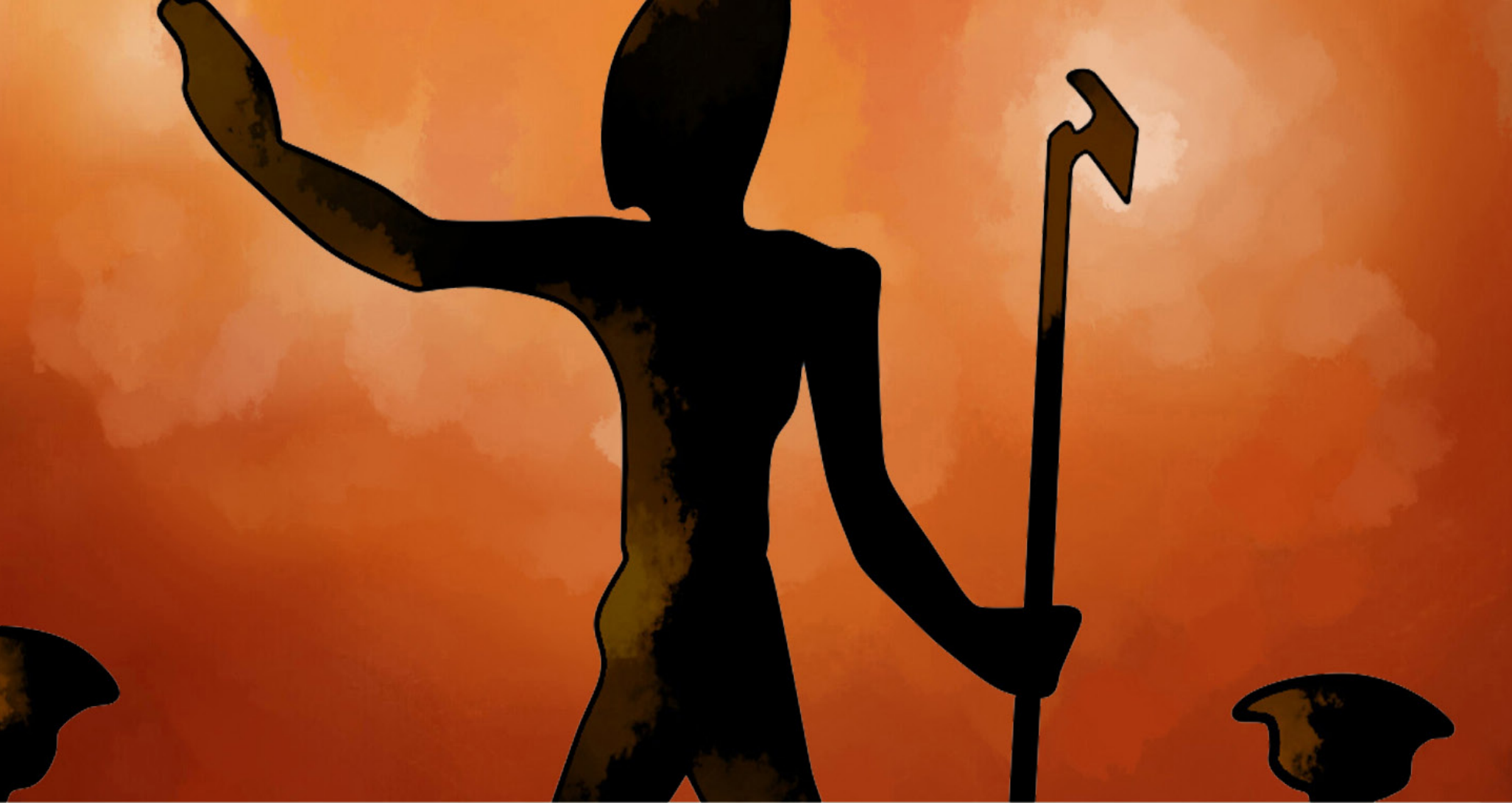

\section{cepoAt}

UNIVERSIDAD DE MURCIA

centro de estudios del

próximo oriente y la

antigüedad tardía 